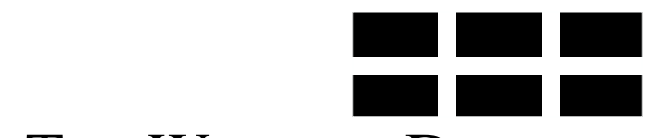

THE WILLIAM DAVIDSON INSTITUTE AT THE UNIVERSITY OF MICHIGAN BUSINESS SCHOOL

\title{
Consumers' Opinion of Inflation Bias Due to Quality Improvements
}

\author{
By: Jan Hanousek and Randall K. Filer
}

William Davidson Institute Working Paper Number 681

May 2004 


\title{
Consumers' Opinion of Inflation Bias Due to Quality Improvements
}

\author{
Jan Hanousek and Randall K. Filer ${ }^{*}$
}

March 2004

\begin{abstract}
Measurement of quality changes has proven to be an especially difficult aspect of calculating unbiased rates of inflation. We propose a new methodology of capturing quality improvements based on consumer focus groups and apply this methodology in an environment where quality changes might be expected to be especially rapid and extensive, a post-communist transition economy. We find that the methodology indicates a substantial understatement of quality improvements during transition, and, therefore, a substantial overstatement of inflation resulting in a serious downward bias in growth rate estimates for post-communist economies. The move to free markets has apparently improved consumers $=$ welfare more by improving what they can purchase than by increasing how much they can purchase. Overall, mismeasurement of quality changes may have understated Czech growth rates during the first decade after communism by as much as 5 percentage points per year.
\end{abstract}

JEL: $\quad$ C82, E31, P24

Keywords: Inflation Bias, Quality Change, Transition Economies, Czech Republic

\footnotetext{
* Jan Hanousek is Citibank Associate Professor of Economics at CERGE-EI, a joint workplace of Charles University and the Academy of Sciences of the Czech Republic, Politických v $\square \mathbf{z} \mathfrak{I} \mid$ 7, 11121 Prague 1, Czech Republic, e-mail: jan.hanousek@cerge.cuni.cz. Randall K. Filer is Professor of Economics at Hunter College and The Graduate Center, City University of New York and CERGE-EI, e-mail: rfiler@hunter.cuny.edu. Professor Hanousek is a Research Fellow at CEPR, London. Professor Filer is a Research Fellow at IZA, Bonn and CESifo, Munich. Both are Research Associates of the William Davidson Institute. This research was supported in part by grants P97-8119-R from the PHARE/ACE program of the European Union and II/75831 from the Volkswagen Foundation. The authors gratefully acknowledges comments from participants in the PHARE/ACE workshop held at CERGE-EI in February 2000 and from Michael Burda, Ivona Kovacs and Emil Stavrev on earlier drafts of this paper.
} 


\section{Introduction and Motivation}

The necessity to obtain accurate price measurements is particularly important in transition economies that need to restrain government revenues (and therefore tax rates) in order to promote economic growth at a time when political realities dictate large social programs, often indexed to inflation, to mitigate the effects of the transition. Upwardly biased measures of inflation that overstate apparent income declines during the transition will have clear domestic political consequences, reducing public support of necessary reforms and increasing political instability. In addition, countries seeking European Union membership face considerable pressure to conform to the Maastricht criteria for accession to the European Monetary Union, among which are a low inflation rate (no more than $1.5 \%$ above the average inflation rate of the three lowest inflation countries in the EU). Obviously, upwardly biased inflation measures make achieving this criterion more difficult. Similarly, if inflation rates are overstated and, therefore, real incomes understated, citizens of accession countries will appear poorer than in reality theyare, thereby increasing pressure for resource transfers from current members and limitations on labour mobility, making the accession negotiations needlessly difficult.

It has long been recognized that quality improvements pose special problems in calculating measures of inflation including Consumer Price Indices (CPI). As Nordhaus (1998, p. 61) put it:

Quality change poses severe problems for a statistical agency. It is non-mechanical in the sense that there is no way to determine quality change on a routine basis. It is heterogeneous in the sense that each quality change is sui generis and, like a child, requires individual attention. It is informationally demanding because it may require vast quantities of data that are expensive to obtain and often do not pass the test of a market transition. Even though routine procedures are established to handle quality change, in the end quality decisions require the subjective judgement about the extent of quality change, and agencies are reluctant to make subjective judgements.

Greenlees (2000, p. 60) is even less optimistic, saying Aquality adjustment is also important because it is so difficult.... Moreover, there are few common solutions to the problems that arise.@ A recent attempt to measure the total extent of bias in the U.S. Consumer Price Index reported that Aof the several issues surrounding the topic of CPI bias, measuring quality change is easily the most controversial, both because estimates of the quality-change bias are often large and because 
estimates of bias frequently involve a large judgmental component and are inherently uncertain@ (Lebow and Rudd, 2003, p. 172).

Despite its difficulty, a great deal of effort is expended by statistical agencies throughout the world in attempting to adjust reported measures of increases in consumer prices for quality changes. Greenlees (2000) and Reinsdorf et al. (1996) discuss the adjustments made in the U.S. while Lowe (1998) summarizes Canadian practice and Armknecht and Mitland-Smith (1999) look at techniques used in a number of countries.

Not withstanding these efforts to capture quality changes, there is a widespread consensus that a substantial fraction of such changes remains unobserved, leading to an upward bias in CPI measures. In the U.S. the Boskin commission from the mid-1990s estimated that the annual bias from unmeasured quality change amounted to 0.6 percentage points, more than half of the total bias they identified and one fifth of average U.S. inflation rates at that time (Boskin, et al., 1998). ${ }^{1}$

The difficulties involved in adjusting for quality changes in measuring inflation can be seen from an examination of currently widely-used techniques and their limitations. Moulton and Moses (1997) report that in a typical month in the U.S. approximately 4 percent of sample price points involve item replacement because the previously sampled item is not available. Overall, some 30 percent of items scheduled to remain in the sample for a full year must be replaced sometime in that year. Of the items that must be replaced, BLS experts decide approximately 65 percent of the time that the new item is comparable to the version no longer available and do not make any quality adjustment. In the remaining 35 percent of cases, some form of quality adjustment is applied (see Schultze and Mackie, 2002 for a discussion of alternatives).

1) The least common technique, the overlap method, is applied to slightly over 1 percent of items replaced. It is based on simultaneous observation of prices for both the old and new versions of the product. The price change associated with quality change is estimated as

\footnotetext{
${ }^{1}$ See Hulten (1997) and Moulton and Moses (1997) for critiques arguing that in theory quality biases could be smaller than found by the Boskin commission. Lebow and Rudd (2003) report that, after recent procedural changes by the Bureau of Labor Statistics (BLS), their best estimate of the extent of upward quality-change bias in the U.S. CPI is 0.37 percentage points a year.
} 
the difference in the market prices in this overlapping period. At the moment when the new product substitutes for the old one in the consumer basket, the price difference between the new product $=\mathrm{s}$ price in period $\mathrm{t}$ and the old product's price in period $\mathrm{t}-1$ is divided between a pure price increase and the quality change estimated from the overlapping period:

$$
\begin{aligned}
& p_{t-1}^{\text {new }}-p_{t-1}^{\text {old }}=\Delta \\
& p_{t}^{\text {new }}-p_{t-1}^{\text {old }}=\delta p_{t}+\Delta
\end{aligned}
$$

This method may produce distorted results if a producer initially offers the new version at the same price as the previous one, but later adjusts prices to reflect true quality differences. In addition, it requires that both the old and new product version be traded in the same outlet at the same time, something that rarely happens.

2) Quality changes can also be inferred from related products using either a link or class mean imputation, a techniques used for about 23 percent of item replacements in the U.S. First a price index $\delta p_{t}^{n-1}$ is calculated based on other, similar goods for the month when a new version of a product is introduced. The percentage change in price between the new and old versions of the product is then decomposed into a price increase effect, assumed to be the same as that for other products of a similar nature, and a residual that is defined as quality change. ${ }^{1}$ This methodology suffers from the required assumption that the price behavior for the item being replaced will be the same as for other, continuing items. For example, if producers use new-model introductions as an opportunity to make unusually large price increases, or if old models are heavily discounted prior to being discontinued, this method will overstate quality changes. On the other hand, if producers discount new models as part of an introduction strategy (for example, by providing discount coupons to encourage consumer sampling of new products), the method will understate quality changes.

3) For approximately 11 percent of item replacements, quality improvements are calculated

${ }^{1}$ The difference between the link and class mean methods lies in the set of comparison items used, with the link method assuming that the pure price change is the same as for the composite of all other goods in the CPI stratum, while the class-mean method uses only the subset of items in the stratum for which there has been a comparable item replacement or direct adjustment of quality change during the period. 
by a direct quality adjustment, based on either the market value of measurable differences in physical characteristics when such differences have been priced independently or the change in production cost associated with added product features. Such adjustments can be made only when the quality improvement involves previously optional characteristics becoming bundled into the standard version of the product or where reliable incremental cost data can be isolated by manufacturers. Examples might include air bags and anti-lock brakes for cars, or modems and CD-ROM drives for computers.

For specific products the direct cost adjustment relies on hedonic regressions. ${ }^{2}$ In this procedure, price is regressed on characteristics of the specific good and the coefficients given by this price-quality relationship used to deduce the "true" value of the new products by applying estimated coefficients to measured differences in characteristics between the old and new goods (see, for example, Feenstra, 1995 and Triplett, 1990). The U.S. Bureau of Labor Statistics has used such adjustments for a number of years and has recently announced a major expansion of quality adjustments derived from hedonic models (see Fixler et. al. 1999; the series of studies for various products reported at http://stats.bls.gov/cpihome.htm; Schwartz and Scafidi 2001). Such a methodology requires that a wide array of product varieties with differing identifiable characteristics be available in the market at the same time.

Recently Bils and Klenow (2001) have proposed an innovative method of inferring quality improvements over time based on instruments derived from cross-section Engle curves relating expenditure for consumer durables to consumer incomes. The assumption is that the higher prices paid by higher income consumers for specific durables, such as a washing machine, represent the purchase of higher quality items. This enables an adjustment for predicted quality increases as overall levels of consumer incomes rise over time. They find that for a sample of 66 items, BLS quality adjustments capture approximately 40 percent of the predicted quality growth across goods, leaving the remaining 60 percent of true quality growth to show up as an overstatement of inflation rates.

Clearly, there are problems with all of these techniques. As with hedonic regressions, the

${ }^{2}$ Examples in the U.S. CPI include computers, televisions, audio equipment, college textbooks, clothes washers and dryers, DVD players, microwave ovens, refrigerators, and videocassette recorders. 
methodology proposed by Bils and Klenow requires there to be a wide variety of versions of specific products on the market at one time to estimate the cross-section Engle curves. No method will capture subtle quality changes within a product if these are embedded in the product without an identifiable model change. For example, no technique would observe that fresh milk had a longer shelf life or that new treatment methods made an otherwise identical shirt more wrinkle free.

Given the data and methodological problems with current techniques for adjusting for quality changes over time, innovation is required. Diewert (1996) challenged readers as follows: "In order to appreciate how choice sets have changed over time, I invite each (older) reader to think about the bundle [of] goods and services that he or she consumed as a youth." We take up this challenge in a specific context, that of the post-communist Czech Republic. We start with the rather obvious assumption that the best way to ascertain the extent to which consumers believe the quality of the products they purchase has changed is to ask the consumers themselves.

While we believe that the methodology we have used has general applicability, we have chosen to apply it to the transition Czech Republic for several reasons. First of all, the very nature of the transition means that the sort of small, embedded quality changes that the method is particularly well-suited to capturing will be especially common and occur in an especially rapid time frame. In 1990, for example, "fresh" milk sold in the Czech Republic came in a plastic container that gave the milk a chemical smell and resulted in spoilage in less than two days. By 1996 fresh milk from the same dairy came in a paper-pack that assured a natural smell and had durability that was guaranteed for four days. At the start of transition jam from local producers came in a jar with a pry-off cap that could not be resealed and often contained fruit pits and stems. Within a few years the fruit was pitted and the caps could be screwed on and off at will. Similarly, film colors became true and batteries lasted several times as long.

Secondly, mismeasurement of inflation due to factors such as quality improvements poses fundamental problems for understanding the transition from planned to market economies. As Filer and Hanousek (2000) have pointed out, eliminating even a relatively minor overstatement of the inflation rate by 20 per cent "would show that every country in the region grew during the 1990s, turning a story of decline and disruption into one of growth and hope.” (p. 293, see also Duchene and Gros, 1994). Quality improvements are likely to be an especially important source of bias in transition economies, largely because initial quality levels were so low. As Stiglitz (1994) and others have pointed out, specification of quality is much more difficult than 
specification of quantity. Thus, command economies, where personal rewards to management depend on plan fulfillment, have a natural tendency to economize on effort and other resources by continually reducing quality, while meeting numerical quantity goals for imprecisely specified goods.

In this paper we use consumers' expressions of what they would be willing to pay for older versions of products conditional on the current versions' price to derive an indication of their perception of quality differences between current and pre-transition products. Examining 63 products from a wide variety of sectors, consumers in the Czech Republic reported that if they were to purchase the 1990-quality product today they would be willing to pay, on average, only 54 per cent of what they pay for the current-quality product for the earlier version. This implies that the actual price increase for these products during the decade was 66 per cent instead of the official 139 per cent.

\section{Methodology}

We derive our results from a series of focus groups conducted in the Czech Republic between March and May, 2001. Focus groups have previously been used by economists to determine the price consumers might be willing to pay for hypothetical products and services such as environmental amenities. ${ }^{3}$ Among enterprises, focus groups are widely used to investigate consumer acceptance of potential new products prior to their launch, including issues of appropriate pricing for such products. ${ }^{4}$ Thus, it seems appropriate to extend the methodology to investigate how consumers would value older, presumably lower quality, products that are no longer on the market relative to how they value today's version of these products. In effect, we asked consumers: "Given the price and quality of a product in the CPI basket today, what would be a reasonable price for the quality characteristics of the same product as it existed at the start of the transition were you able to purchase this older product today?" ${ }^{5}$ The difference in these prices

\footnotetext{
3 See Soderholm (2001); Hanley et al. (2001); Kaplowitz and Hoehn (2001); Kontogianni et al. (2001); Ortuzar, Iacobelli and Velez (2000); Chilton and Hutcheson (1999); Freeman and Rogers (1999); Beattie et al (1998); Knoppers and Mathios (1998); Kramer and Mercer (1997), Lunt (1996), Johnston et al (1995), Desvousges and Smith (1988), and Mitchell and Carson (1986).

${ }^{4}$ See Bernacchi (2001); Samel and Henthorne (1993) for examples and Feick et al. (1995) for a use of focus groups in evaluating consumer experiences in the transition.

${ }^{5}$ While it might at first appear that our methodology has much in common with contingent valuation studies, there is a fundamental difference. Contingent valuation involves asking consumers what they would be willing to pay for a
} 
represents the difference in the quality of the item, expressed in today's currency. Only price increases in excess of this difference can be said to represent true inflation.

We engaged a firm with extensive experience in market research in the Czech Republic to conduct these focus groups. Each group was composed of men and women aged 33 to 55 who were the head or spouse of a head-of-household in 1990 and who had secondary or higher education. ${ }^{6}$ We ran a total of 15 focus groups, nine containing women and six containing men. Each group consisted of six individuals who evaluated approximately ten independent products from a variety of the major categories in the consumer basket. Each product was evaluated by between one and seven independent groups, with the average product being discussed by 2.4 groups. Appendix table A-1 shows the number of focus groups and respondents for each item. ${ }^{7}$ Each focus group followed a similar script.

1) The moderator presented a product as it existed in 1990 (using a photo or the actual product if available). Group members were asked to recall this particular product and discuss its typical features and what they liked and/or disliked about it. The members of the group worked together to reach a consensus view of the characteristics of the earlier product.

2) The current version of the product was presented and the group discussed its characteristics and how they differ from the product as it existed in 1990.

3) The moderator distributed a record sheet for the product under discussion and asked group members to carefully consider all the differences between the current version of the product and the product as it existed in 1990. The moderator then revealed the current price

hypothetical product or service with which they have no actual experience. We, on the other hand, are asking consumers about appropriate relative prices for two products with which they have actual experience. In general, differences between willingness to pay and willingness to accept have been shown to be smaller when close substitutes exist for the product in question (Shogren, 1994; Adamowicz, Bhardwaj and Macnab, 1993). Surely there can be no closer substitutes than old and new versions of the same product. Moreover, the difference is generally assumed to arise from informational discrepancies between products with which consumers have experience and those that are unknown to them (Kolstad and Guzman, 1999). In our case, consumers have full information on both the old and new versions of the products, having actually consumed both.

${ }^{6}$ We excluded those less than 33 years of age since they were not likely to be main shoppers and have well-developed product knowledge from ten years earlier when they were 23 or younger. In the Czech Republic fewer than 10 percent of workers in this age group have less than a secondary school education. These are likely to be recent immigrants or members of minority groups from whom it would be difficult to elicit reliable data in the current research framework. Within the age group and education level specified, respondents mirrored the Czech population distribution.

${ }^{7}$ The number of respondents is not always a perfect multiple of six since, on occasion, an individual opted not to participate at the last minute and was not replaced, causing this group to have five members. 
of the product ${ }^{8}$ and asked, "if both versions of the product were sold on the market today alongside each other what would you consider to be a fair and appropriate price for the 1990 version, provided that the current version costs ___ crowns? $?^{9 "}$

4) After the price was assigned individually by the respondents, the individual choices were discussed among the group. The moderator would probe to elicit discussion of why the participants assigned the relative prices they did.

5) At the end of the session, after discussing about ten different products, respondents were asked again to record their relative evaluations for each product. This gave respondents a chance to revise their evaluations in light of the group discussion and the patterns revealed across the several products being considered. We retained both the initial and revised evaluations although there were minimal differences. Results below are based on the revised figures.

${ }^{8}$ Defined as the official price in the December 2000 market basket as determined by the Czech Statistical Office (CSO).

${ }^{9}$ We tried a number of alternative wordings of this question in developing the study. Debriefing of participants led us to believe that the version asked elicited responses that were closest to the economist's conceptual ideal, e.g. "what price would leave the consumer indifferent between the old and new versions of the product?" It should be noted that the old and new versions are such close substitutes that it is unlikely that any particular consumer would purchase both at the same time. 


\section{Results}

The Czech consumer price basket consists of approximately 750 individual referent items defined at a level such "mayonnaise" or "leather walking shoes for boys." There have been almost no changes in these broadly defined items during the 1990s, although the specific brand or model priced for each item may have been changed several times and may differ across different sample points (stores) at any given time. Our focus groups evaluated 63 items that comprised 16.2 per cent of the total weight in the consumer basket as of 1990 and 15.8 per cent of the total weight in $2000 .^{10}$ The specific items were chosen to encompass all strata, and within strata, to be both varied in nature and among the most heavily weighted items.

Table 1 reports the results for these 63 products. The second column shows the price of the referent good in official data in 1990 while the third column shows the price for the same item in December 2000. The fourth column shows the percentage increase in prices between 1990 and the end of 2000. The Czech Statistical Office (CSO), however, made conventional adjustments in months when there was an obvious change in the referent item sampled. Thus, column 5 shows the official increase in the price index for each item after incorporating any CSO adjustments, Column 6, which is the difference between Columns 4 and 5, therefore, shows the part of the increase in prices excluded by the CSO through adjustment for quality changes.

\footnotetext{
${ }^{10}$ This compares with the 12.4 percent of the U.S. consumer basket represented by the items studied by Bils and Klenow (2001), or the 7.0 percent of the U.S. basket for which estimates of quality-change bias are based in what Lebow and Rudd (2003, p. 174) report as having "at least a moderate degree of hard evidence."
} 
Columns 7 though 9 contain the heart of our research. Column 7 shows the median ${ }^{11}$ response among our focus-group members to the question "What would be a fair price today for the 1990 version of product X, given the actual price charged today for the current version of the product?" In order to obtain a measure of the dispersion across respondents, it also shows the $25^{\text {th }}$ and $75^{\text {th }}$ percentile of answers to this question. ${ }^{12}$ Column 8 , showing the percentage difference between these hypothetical current prices for the 1990 version of the product and the actual market price for the current version of the product (column 3), represents consumers' opinion of the value of the difference in quality between these two product today. Finally, column 9 indicates the percentage difference between the actual 1990 price of the product (column 2) and what consumers' would be willing to pay for the constant-quality version of the product today (column 7). As such, it represents the true cumulative inflation rate for this product purged of the effect of quality changes. Again, both the median and $25^{\text {th }}$ and $75^{\text {th }}$ percentile of responses are shown

Looking at the first row of data in Table 1 makes the importance of adjusting for hidden quality improvements clear. In 1990 a liter of milk sold for 2.8 crowns while in December 2000 it sold for 12 crowns according to official price data. This was a 329 per cent increase, as shown in column 4. There were no significant adjustments made by the CSO, so the official price increase used for calculating the CPI over this period was 333 percent as shown in column 5. Consumers who were asked to recall the characteristics (including packaging, flavor and shelf life) of milk as they existed in 1990 and evaluate how much they would be willing to pay for such milk today, reported that, on average, 8 crowns would be a fair price given that milk with today's characteristics sold for 12 crowns. Twenty-five per cent would be willing to pay 6.5 crowns or less for 1990 variety milk today and 25 per cent more than 8 crowns. The value of the increased quality is the difference between today's price of 12 crowns and the hypothetical "fair" price for the older quality product of 8 crowns today or 50 per cent as shown in column 8 . Thus, for the median consumer the actual price increase for milk of constant quality is not 329 per cent, but the 186 per cent shown in column 9 that results from an increase from 2.8 crowns per liter in 1990 to a hypothetical price of 8 crowns for the 1990 product version today. At the $25^{\text {th }}$ percentile of hypothetical current prices for the 1990 product, consumers report a quality improvement of 85

\footnotetext{
${ }^{11}$ Results are virtually identical if we use the mean response instead.

${ }^{12}$ With small samples the inter-quartile range is a better measure of dispersion than standard deviations
} 
per cent and a price increase of 135 per cent. ${ }^{13}$

We asked focus groups about a variety of products from across the consumer basket. The items evaluated cannot be claimed to be random, but they do account for a sixth of the entire basket and were not explicitly selected to be ones with large presumed quality changes. Instead, we selected items that were relatively large within their stratum and appeared to reflect the variety of items within the stratum. The average price increase for all products we surveyed, weighted by their share in the consumer basket, was 150 per cent, while the official increase in the CPI for these components after all adjustments by the CSO was 139 per cent, implying that the CSO found only 8 per cent of the price increase to be due to quality improvements. ${ }^{14}$ Our focus group respondents, however, found the average quality improvement across the 63 products to be 86 percent. In other words, they reported that they would be willing to purchase the 1990 quality product today only if it were to be sold at a price averaging 54 per cent of the price for the current quality product. ${ }^{15}$ Similarly, our results imply that the actual increase in prices for the decade for these products was 74 per cent instead of the official 139 per cent. ${ }^{16}$ On an annual basis, the official inflation rate across all these items (weighted by their share in the consumer price basket) during 1990s was 9.1 per cent after official quality adjustments (and 9.6 per cent a year without such adjustments). When consumers' perceptions of quality improvements are allowed for, however, the annual increase in prices is reduced to approximately 4.3 percent. ${ }^{17}$

${ }^{13}$ Given that prices at the median and $75^{\text {th }}$ percentile for the 1990 product are the same, there is no difference in reported quality and price increases for these percentiles.

${ }^{14}$ While there is a positive relationship between the extent of quality improvement found by the CSO (column 6 ) and that reported by our focus groups (column 8), the overall correlation between these figures is only 0.05 .

15 An additional two items evaluated by the focus groups have been excluded from the analysis because the groups concluded that the 1990 quality was so low that the proper current price would be zero or negative, implying an infinite quality improvement. These items were hair coloring and hair permanents. Respondents indicated that the damage the earlier versions inflicted on their hair meant that they would not purchase them at any price if the current version were available. Thus, these items had an infinite implied quality improvement. Assuming that they had a price change of -100 per cent has trivial impact on overall weighted average price changes. The same cannot be said for the implicit infinite quality change, however, since any positive weight assigned to them would mean that overall quality change was also infinite.

${ }^{16}$ While a seemingly large difference, these results are consistent with those derived from surveys conducted in Romania in 2000, where consumers who reported their economic situation in terms of purchasing power to be "about the same as last year" reported income increases of less than half of the official inflation rate (Filer and Hanousek 2001).

${ }^{17}$ This is the geometric mean of the implicit inflation rates generated from the weighted average quality improvement 
We can obtain an indication of the precision of this conclusion by examining results for the $25^{\text {th }}$ and $75^{\text {th }}$ percentiles of reported quality change. Assuming that the lower extent of quality change yields an estimated weighted average quality change of 64 per cent, and an estimated annual rate of price increase of 5.4 per cent a year. If we assume that the actual quality change lies at the $75^{\text {th }}$ percentile of responses from our focus group members, the weighted average quality change across our 63 products would be 134 per cent and the implicit annual rate of price increase would be 1.6 per cent. ${ }^{18}$

The results in Table 1 are grouped according to broad categories of goods. The patterns are intuitively appealing, giving confidence that the focus group methodology is sound. Reported quality improvements are smallest for food and beverages, standardized and relatively simple items. Thus, the vast majority of the price increase of somewhat over 100 per cent for these items was true inflation. Indeed, for some foodstuffs, our consumer groups reported no quality improvement or even a quality decline since the end of communism. Our respondents reported the greatest increase in quality for personal care products and recreational products, followed by clothing and home care products.

If we assume that other items within each broad product group behaved in the same way as those we sampled, then scaling up the sampled items to reflect weights for the full consumer basket implies a slightly greater official index increase of 152 per cent, a median quality improvement of 71 per cent, and a median true price increase of 77 percent, results very close to those for our sample reported above.

(3.2 per cent) and weighted average actual price increases ( 5.7 per cent). The range is generated by the nonlinearities implicit in taking weighted averages of quality changes and actual price changes across individual items.

18 Again, these are the geometric means of the rates of increase in prices derived from weighted quality changes and weighted actual price increases. The extreme bounds would be 0.6 per cent price increase per year using the actual $75^{\text {th }}$ percentile of quality change ( 134 per cent) and 6.9 per cent price increase per year using the weighted average actual price increase implied by quality changes at the $25^{\text {th }}$ percentile ( 95 percent). 


\section{Conclusions}

Overall, it appears that the Czech Statistical Office has captured only a fraction (at the median, perhaps 15 percent) of the quality change that our respondents believe has occurred over the first decade of the transition. This figure compares with the 40 percent that Bils and Klenow (2001) suggest the BLS captured in the U.S. Intuitively, the greater uncaptured component of quality change makes perfect sense given the extensive and rapid changes in basic products that occurred as a part of transition and the relative lack of sophistication of the CSO at the start of transition. These results suggest that average quality-adjusted consumption growth rates in the Czech Republic during the 1990s may have been considerably greater than the official figures suggest.

The reader is cautioned, however, to view the findings as preliminary. We have not sampled the full consumer price basket. ${ }^{19}$ More importantly, consumers were evaluating the quality of goods assuming that they were actually available and not assigning any reduction in quality for scarcity. As one group member said during the discussion, "You had to line up for them and couldn't always find baked goods, but when you did you knew they were fresh!" It is hard to know how to evaluate the quality change implicit in reduction of what were often multi-year queuing times for telephone service or rental apartments, but it is clear that the true price increase should be substantially smaller than the recorded monetary price increase in our data once search and scarcity (waiting) costs are factored into prices at the start of the transition. Obviously, this would make quality improvement an even more significant fraction of the real price change.

In addition, the recall period of ten years may impart unknown biases. While we believe that the discussion and revision inherent in the focus group methodology will minimize recall biases, it is possible that individuals have faulty memories regarding the true quality (or lack thereof) of consumer goods produced under communism.

\footnotetext{
19 Although even if there were no quality improvement in the remaining items in the consumer price basket, the biases we have identified in the 16 per cent of the basket we have studied would be sufficient to substantially increase measured growth rates. Of course, the assumption that no other goods exhibited a quality increase is totally unjustified.
} 
Measuring quality change and its impact on price changes is an inherently difficult process. As the Conference Board concluded (1999, p. 21) "there is no alternative to thorough, detailed analyses that slog through the data category by category, item by item. This is difficult, costly work, but no shortcuts are available." We believe that the focus group methodology used in this study adds a useful method of investigating quality changes in at least some items. Like other methods of measuring quality change it will be more useful in some situations than in others. We suspect that the method has the most potential in assessing quality change in products where improvements are small and continuous and will be least useful when there are major considerations of style or fashion.

In this spirit we would call for extension of this research to other transition economies as well as to more items in the Czech consumer price basket, as well as applying the focus group methodology in a developed economy such as the U.S. Results need to be compared with those derived from other methods and a composite picture assembled from the most appropriate method for each product. There is no reason to believe, however, that such extensions would change the bottom line: that a substantial understatement of the degree of quality improvement and, therefore, a substantial overstatement of inflation rates has resulted in a serious downward bias in estimates of growth rates of post-communist economies. The move to free markets has apparently improved consumers' welfare more by improving what they can purchase than by increasing how much they can purchase. 


\section{REFERENCES}

Adamowicz, Wiktor L., Vinay Bhardwaj and Bruce Macnab. 1993. "Experiments on the Difference between Willingness to Pay and Willingness to Accept," Land Economics. 69 (4): 416-27.

Armknecht, Paul A. and Fenella Maitland-Smith. 1999. "Price Imputation and Other techniques for Dealing with Missing Observations, Seasonality and Quality Change in Price Indices," Washington, D.C.: International Monetary Fund Working Paper WP/99/78.

Beattie, Jane, J. Covey, P. Hopkins et al. 1998. "On the Contingent Valuation of Safety and the Safety of Contingent Valuation," Journal of Risk and Uncertainty, 17 (1): 5-25.

Bernacchi, Terry. 2001. "The Challenge of Prescription Drug Pricing," Pharmaceutical Executive, 21 (3): 56-68.

Bils, Mark and Peter J. Klenow. 2001. "Quantifying Quality Growth,” American Economic Review, 91 (4): 1006-1030.

Boskin, Michael J., Ellen R. Dulberger, Robert J. Gordon, Zvi Griliches and Dale W. Jorgenson. 1998. "Consumer Prices, the Consumer Price Index, and the Cost of Living," Journal of Economic Perspectives. 12 (1): 3-26.

Chilton, S. M. and W. G. Hutchinson. 1999. "Do Focus Groups Contribute Anything to the Continent Valuation Process?” Journal of Economic Psychology, 20 (4): 465-83.

The Conference Board. 1999. Measuring Prices in a Dynamic Economy: Re-Examining the CPI. New York: The Conference Board, Inc. 
Czech Statistical Office 1990-2000. Consumer Price Indices: Specification of the Representatives and Their Weights in the Consumer Basket (in Czech), Prague, Czech Statistical Office, mimeo.

Desvousges, William H. and V. Kerry Smith. 1988. "Focus Groups and Risk Communication," Risk Analysis, 8 (4): 479-484.

Diewert, W. Erwin. 1996. “Comment on CPI Biases,” Business Economics. 31 (2): 30-35.

Duchene, G. and Gros, D. 1994. Cases of Output Decline in Reforming Economies, Brussels: Center for European Policy Studies.

Feenstra, Robert C. 1995. "Exact Hedonic Price Indexes," Review of Economics and Statistics, 116 (12): 3-12.

Fieck, Lawrence, Robin Higie Coulter and Linda L. Price. 1995. "Consumers in the Transition to a Market Economy: Hungary, 1989 - 1992.” International Marketing Review, 12 (5): $18-34$.

Filer Randall K., and Jan Hanousek. 2001. "Survey-based Estimates of Biases in Consumer Price Indices During Transition: Evidence from Romania” Prague: CERGE-EI Working Paper 178.

, 2000. "Output changes and inflationary bias in transition,"Economic Systems, 24 (3): 285-294.

Fixler, Dennis, Charles Fortuna, John Greenlees and Walter Lane. 1999. "The Use of Hedonic 
Regressions to Handle Quality Change: The Experience of the U.S. CPI,' Washington, DC: Bureau of Labor Statistics, mimeo (presented at $5^{\text {th }}$ meeting of the International Working Group on Price Indices).

Freeman, Richard B. and Joel Rogers. 1999. What Workers Want, Ithaca: Cornell University Press.

Greenlees, John. 2000. "Consumer Price Indexes: Methods for Quality and Variety Change," Statistical Journal of the United Nations Economic Commission for Europe, 17 (1): 59-74.

Hanley, N., G. Koop, B. Alvarez-Farizio et. al. 2001. "Go Climb a Mountain: An Application of Recreation Demand Modeling to Rock Climbing in Scotland," Journal of Agricultural Economics, 52 (1): 36-52.

Hulten, Charles. 1997. "Quality Changes in the CPI," Federal Reserve Bank of St. Louis Review, 79 (3): 101-105.

Johnston, R. J., T. F. Weaver, L. A. Smith and S. K. Swallow. 1995. “Contingent Valuation Focus Groups.” Agricultural and Resource Economics Review, 24 (1): 56-69.

Kaplowitz, M. D. and Hoehn, J. P. 2001. "Do Focus Groups and Individual Interviews Reveal the Same Information for Natural Resource Valuation?”, Ecological Economics; 36 (2): 237-247.

Kolstad, Charles D and Rolando M. Guzman. 1999. "Information and the Divergence between Willingness to Accept and Willingness to Pay," Journal of Environmental Economics and Management, 38 (1): 66-80. 
Knoppers, Bartha M. and Alan D. Mathios. 1998. Biotechnology and the Consumer. Boston: Kluwer Academic.

Kontogianni, A., M. S. Skourtos, I. H. Langford et. al. 2001. "Integrating Stakeholder Analysis in Non-market Valuation of Environmental Assets," Ecological Economics, 37 (1): 123-38.

Kramer, Randall A. and Evan D. Mercer. 1997. "Valuing a Global Environmental Good: U.S. Residents' Willingness to Pay to Protect Tropical Rain Forests," Land Economics, 73 (2): $196-210$.

Lebow, David E. and Jeremy B. Rudd. 2003. "Measurement Error in the Consumer Price Index: Where Do We Stand?" Journal of Economic Literature, 41 (1): 159-201.

Leigey, Paul R. Jr. 1994. “Apparel Prices Indexes: Effects of Hedonic Adjustment,” Monthly Labor Review, 117 (5): 38-45.

Lowe, Robin. 1998. "Item Selection and Quality Change in the Canadian CPI," Statistical Journal of the United Nations Economic Commission for Europe, 15 (1): 53-76.

Lunt, Peter. 1996 “Discourses on Saving,” Journal of Economic Psychology, 17 (2): 275-287.

Mitchell, Robert Cameron and Richard T. Carson. 1986. "Property Rights, Protest, and the Siting of Hazardous Waste Facilities," American Economic Review, 76 (2): 285-291

Moulton, Brent R. and Karin E. Moses. 1997. "Addressing the Quality Change Issue in the Consumer Price Index," Brookings Papers on Economic Activity, 0 (1): 305-349 
Nordhaus William D. 1998. "Quality Change in Price Indexes”, Journal of Economic Perspectives $12(1): 59-68$

Ortuzar, Juan de Dios, Andres Iacobelli and Claudio Valeze, 2000. "Estimating Demand for a Cycle-Way Network," Transportation Reearch: Part A - Policy and Practice, 34 (5): 353-73.

Reinsdorf, Marshall B. Paul Liegey and Kenneth J. Stewart. 1996. "New Ways of Handling Quality Change in the U.S. Consumer Price Index," Washington, DC: Bureau of Labor Statistics Working Paper 276.

Samel, Ben R. and Tony L. Henthorne. 1993. "The Process for Determining an ATM Pricing Strategy." Journal of Retail Banking, 15 (2): 25-29.

Schultze, Charles L. and Christopher Mackie, eds. 2002. At What Price? Conceptualizing and Measuring Cost-of-Living and Price Indices. Washington: National Academy Press.

Schwartz, Amy Ellen and Benjamin P. Scafidi. 2001. "Quality Adjusted Indices for Four Year Colleges," Washington, DC: Bureau of Labor Statistics Working Paper 337.

Shogren, Jason F. et. al. 1994. "Resolving Differences in Willingness to Pay and Willingness to Accept," American Economic Review. 84 (1): 255-70.

Soderholm, Patrik. 2001. "The Deliberative Approach in Environmental Valuation," Journal of Economic Issues. 35 (2): 487-95.

Stiglitz, Joseph E. 1994. Whither Socialism?, Cambridge, MIT Press. 
Triplett, Jack E. 1990. "Hedonic Methods in Statistical Agency Environments," in E. R. Berndt and J. E. Triplett (eds) Fifty Years of Economic Measurement: The Jubilee Conference on Research in Income and Wealth, Chicago: University of Chicago Press for NBER. 


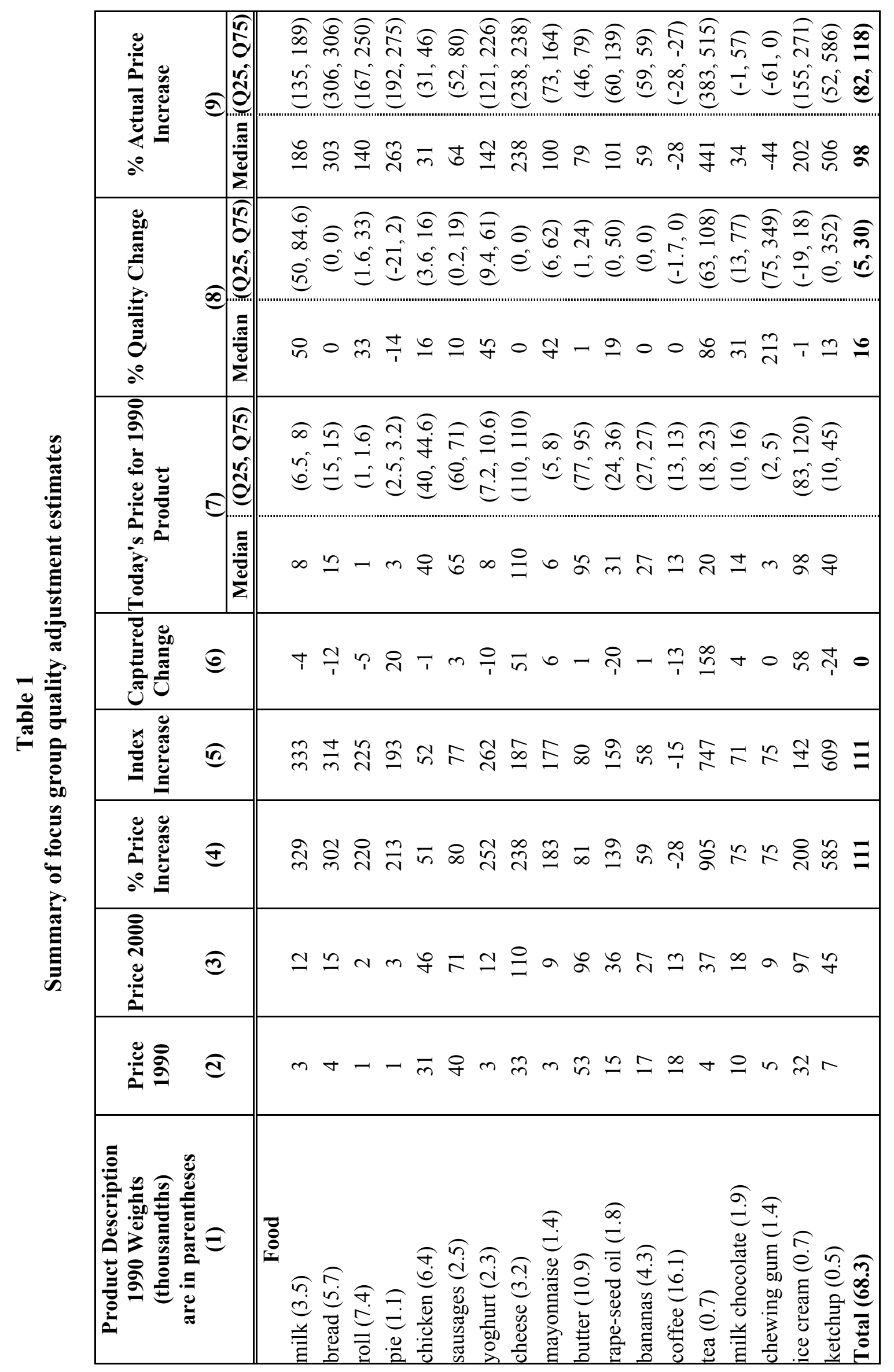




\begin{tabular}{|c|c|c|c|c|c|}
\hline \multirow{2}{*}{ 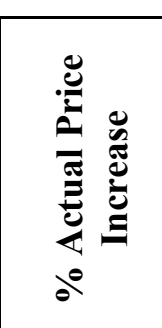 } & \multirow{2}{*}{ 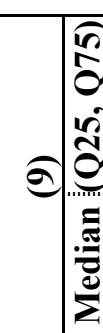 } & 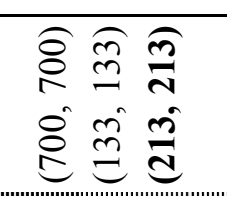 & \multicolumn{2}{|c|}{ 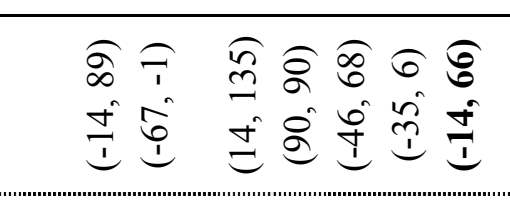 } & 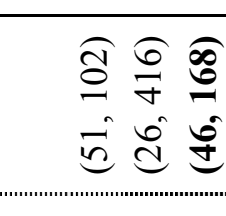 \\
\hline & & 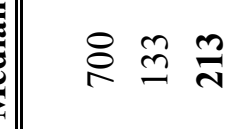 & in 9 & in 8 串 & $\infty \stackrel{n}{m}$ \\
\hline 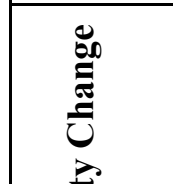 & 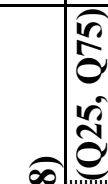 & 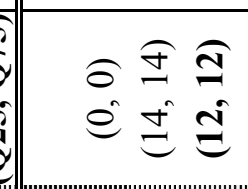 & 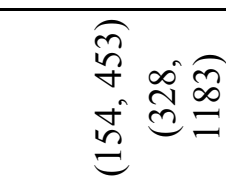 & 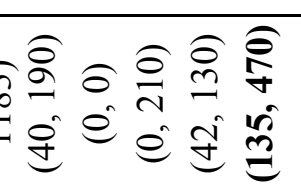 & 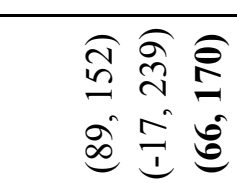 \\
\hline 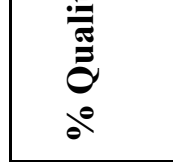 & 槆 & $\circ \pm I$ & 穷 & $\supseteqq 00 \stackrel{\infty}{\Xi}$ & $\stackrel{\infty}{9} \sigma$ \\
\hline 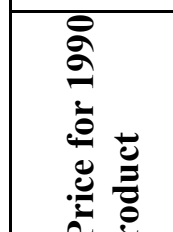 & 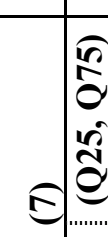 & $\begin{array}{l}\hat{0} \hat{\Omega} \\
\hat{e}: \hat{g}\end{array}$ & 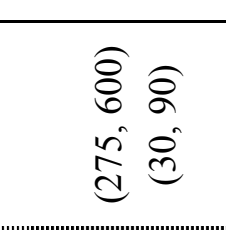 & 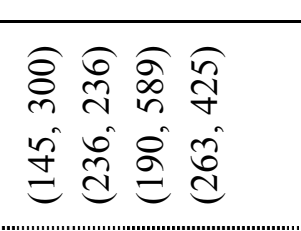 & 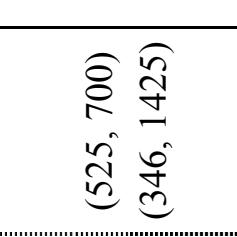 \\
\hline 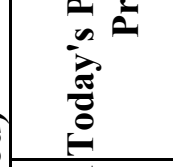 & 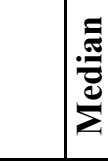 & 68 & $\stackrel{8}{\infty} \infty$ & \&્స & 8 \\
\hline 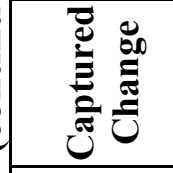 & e & t) & $i n$ & 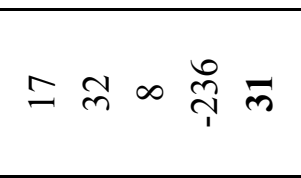 & $\simeq \approx$ \\
\hline 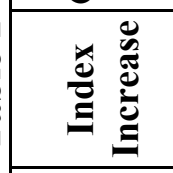 & 6 & ర్రి $: \stackrel{0}{0}$ & $\underset{\sim}{\tilde{N}} \vec{s}$ & $\stackrel{m}{\sim}$ in $\vec{\sigma} \underset{\sim}{\infty}$ iิ & 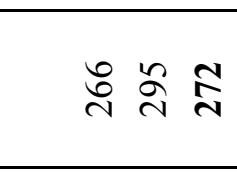 \\
\hline 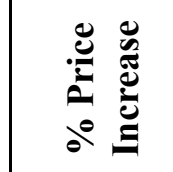 & 丹 & $\stackrel{5}{8}$ & $\underset{\infty}{\infty} \underset{\infty}{\mathbb{N}}$ & 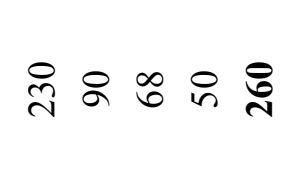 & 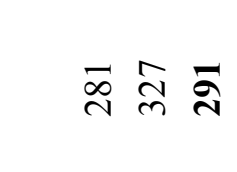 \\
\hline 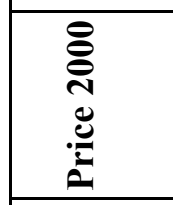 & (3) & $0 \&$ & $\overrightarrow{\widetilde{N}} \stackrel{\infty}{\infty}$ & 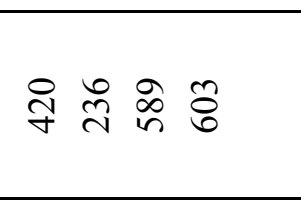 & $\underset{\sim}{\approx} \stackrel{\infty}{=}$ \\
\hline : & $\widehat{d}$ & $-i$ & $\frac{\infty}{m} \vec{\sigma}$ & I记号宗 & $\stackrel{f}{d} \stackrel{\circ}{i}$ \\
\hline 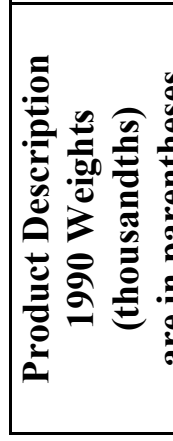 & & 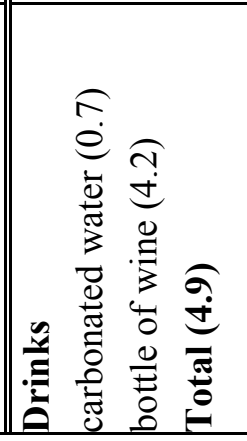 & 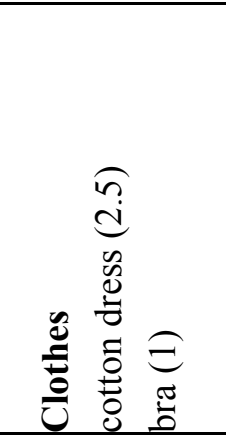 & 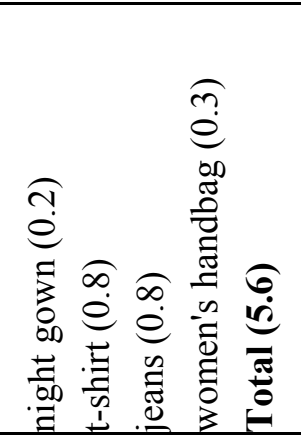 & 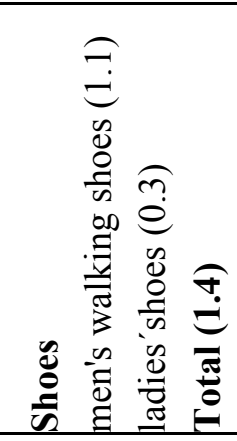 \\
\hline
\end{tabular}




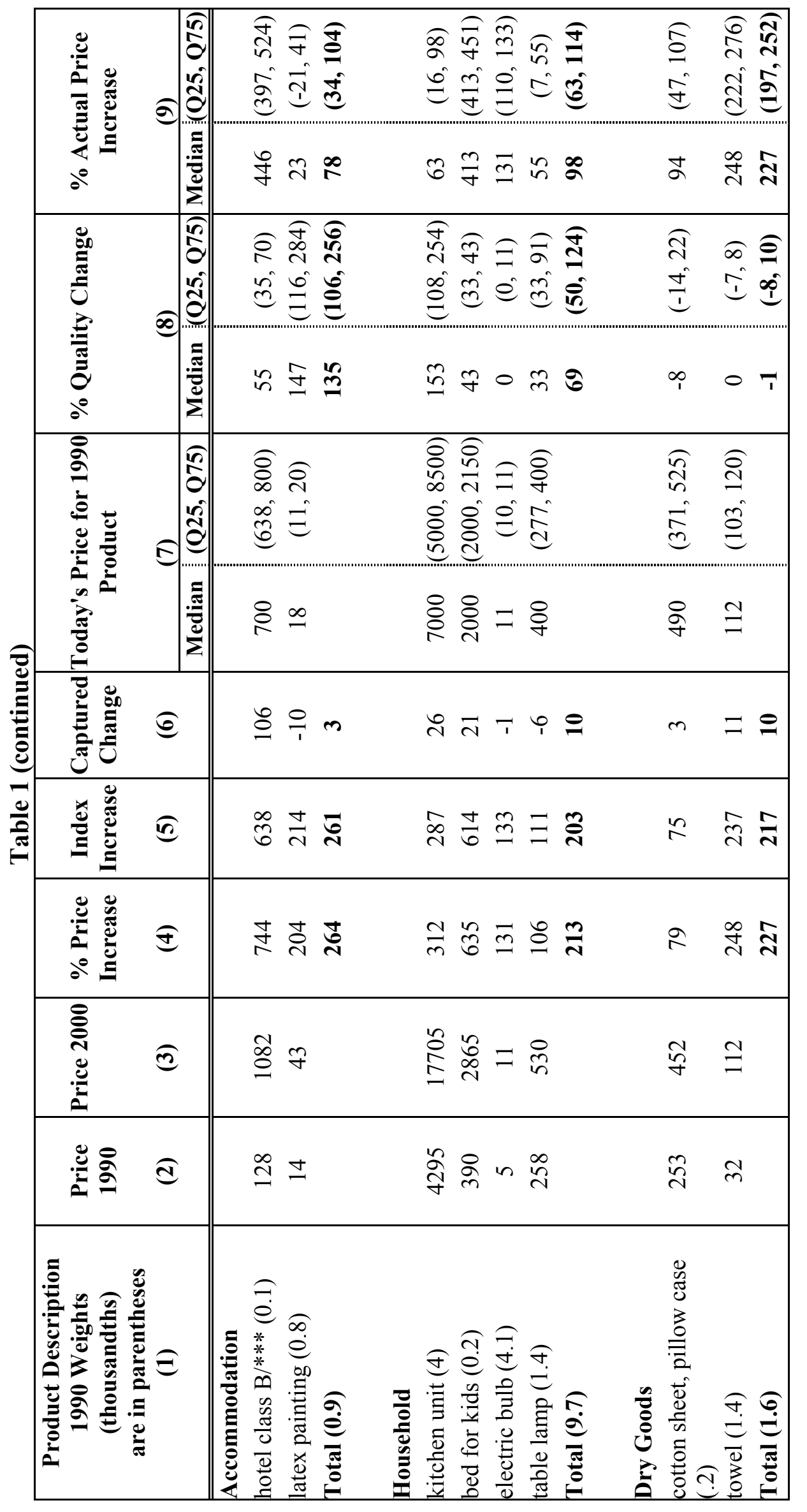




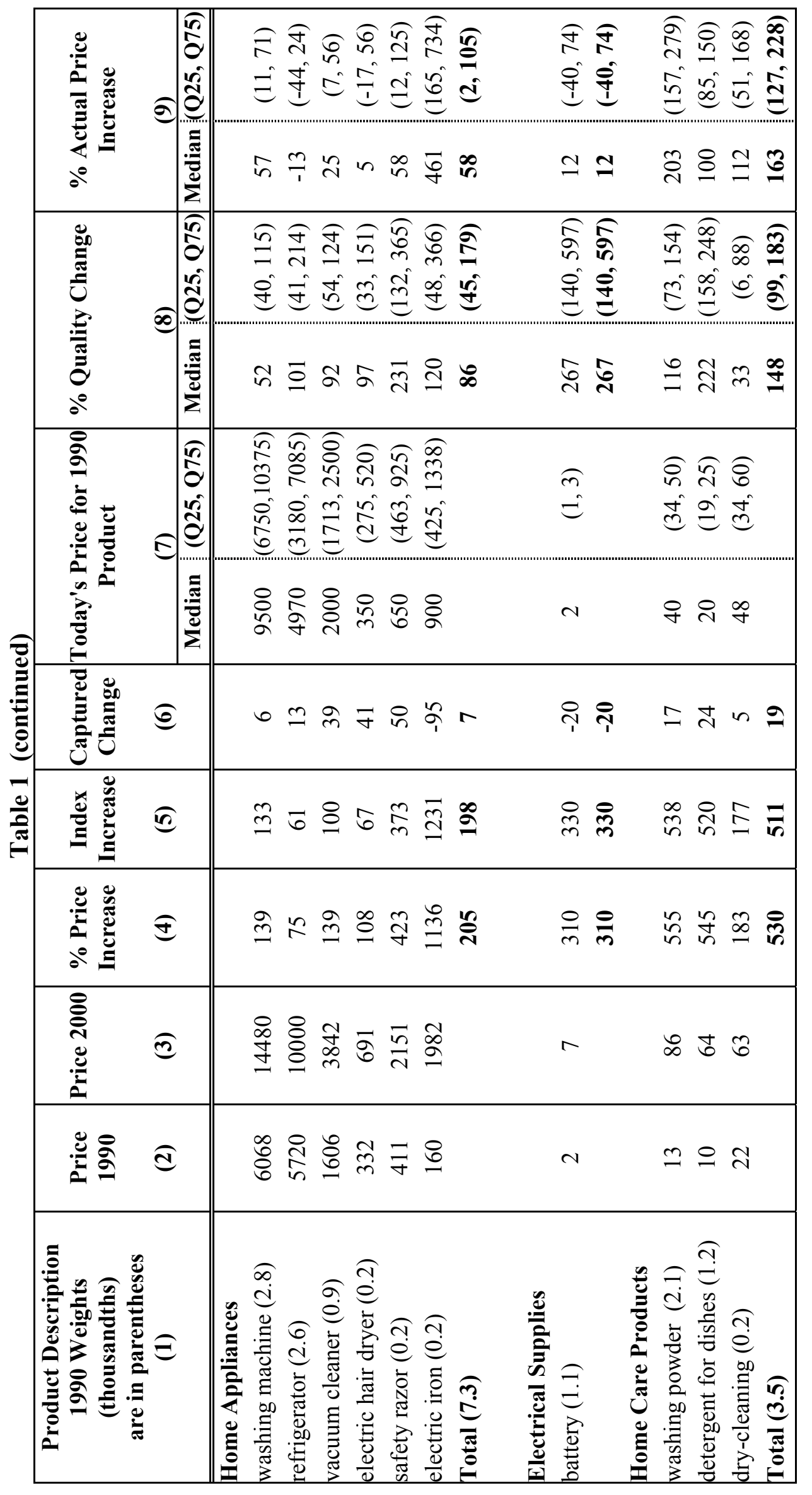




\begin{tabular}{|c|c|c|c|c|}
\hline \multirow{2}{*}{ 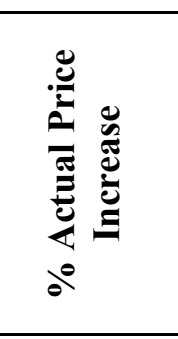 } & \multirow{2}{*}{ 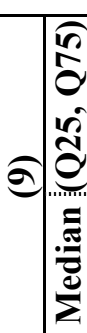 } & 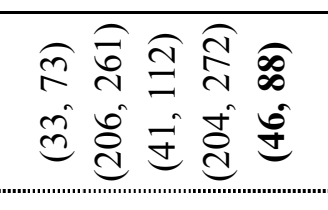 & 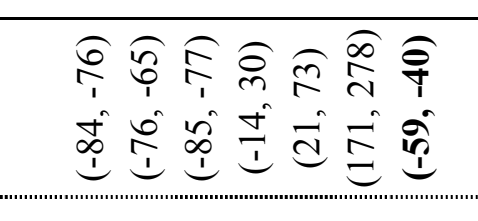 & 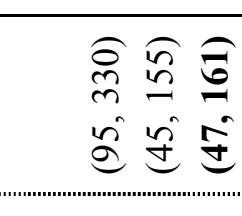 \\
\hline & & i̊ तुำ & 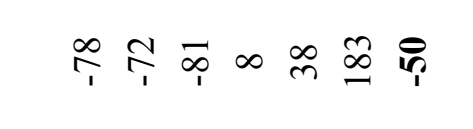 & 象的 i \\
\hline 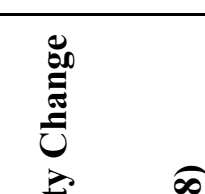 & 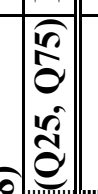 & 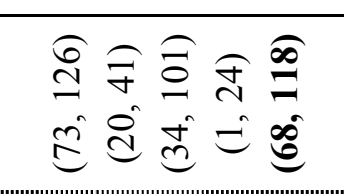 & 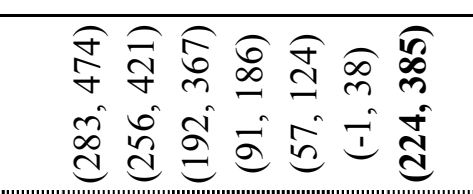 & 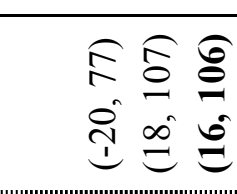 \\
\hline 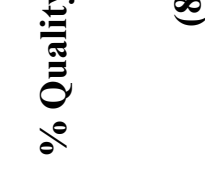 & 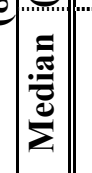 & 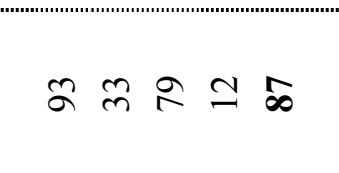 & $\frac{\infty}{m}$ fે & ㄷa \\
\hline 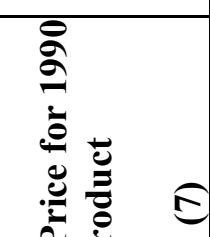 & $=$ & 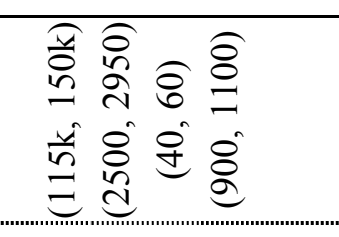 & 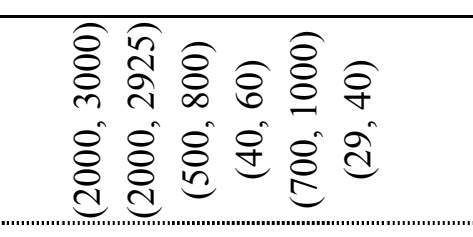 & 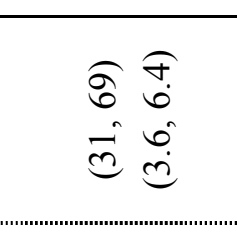 \\
\hline 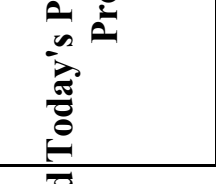 & 竞 & 总 & 究 苂 & $m+$ \\
\hline 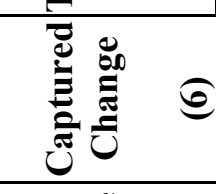 & & ケธ丶万 & $\neg n \uparrow-\infty \infty N$ & noo \\
\hline 总总 & & 点导过过 & ત તి & 웟 \& సิ \\
\hline 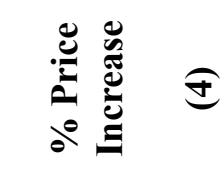 & & 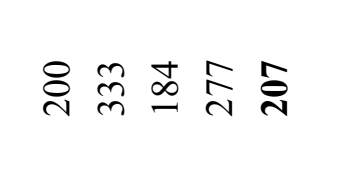 & 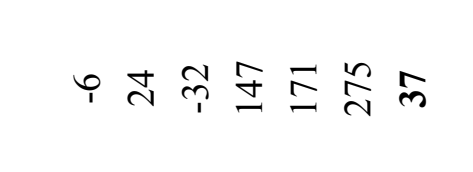 & 尔 \& సิ సี \\
\hline 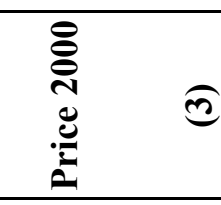 & & 兽 & 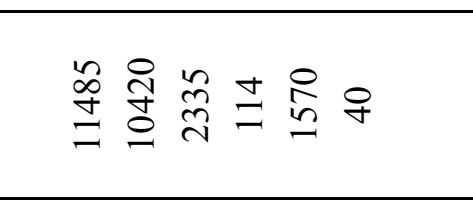 & $i n \infty$ \\
\hline 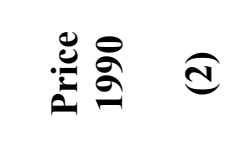 & E & 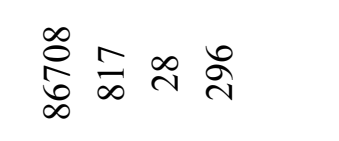 & 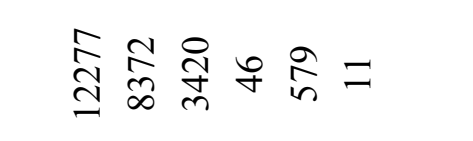 & $\stackrel{\circ}{m}$ \\
\hline 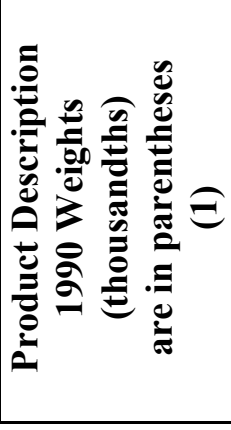 & & 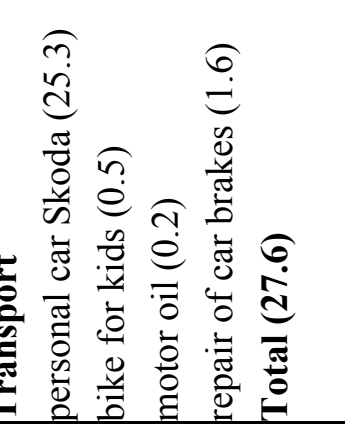 & 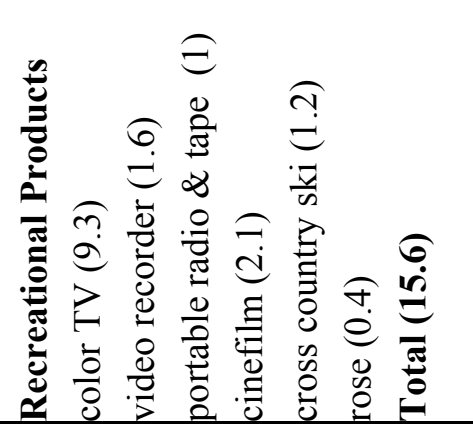 & 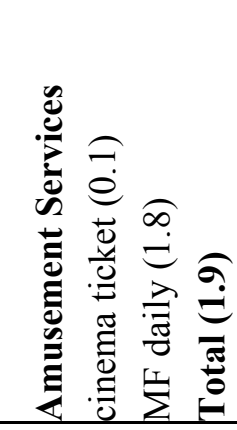 \\
\hline
\end{tabular}




\begin{tabular}{|c|c|c|c|c|}
\hline \multirow{2}{*}{\multicolumn{2}{|c|}{ 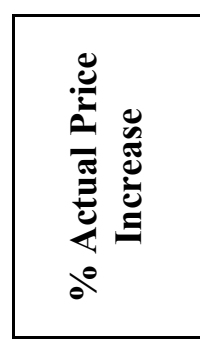 }} & \multirow{2}{*}{ 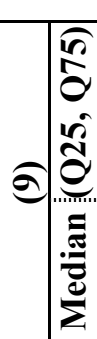 } & 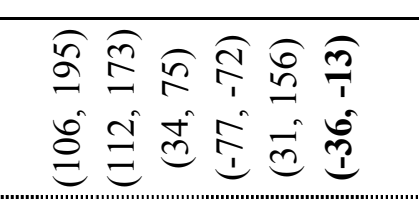 & $\begin{array}{l}\text { אू } \\
\text { î }\end{array}$ \\
\hline & & & $\Leftrightarrow \cong$ & I \\
\hline & 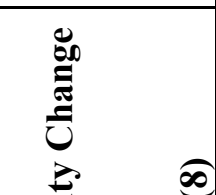 & $\mid$ & 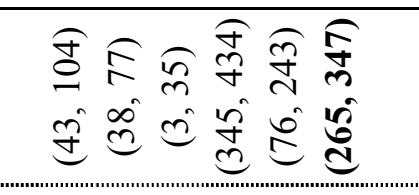 & $\begin{array}{l}\text { f } \\
\text { d } \\
\text { di }\end{array}$ \\
\hline & 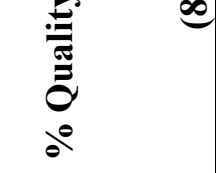 & 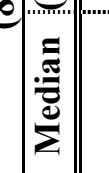 & 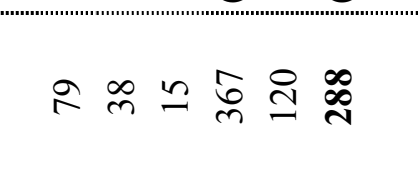 & $\infty$ \\
\hline & 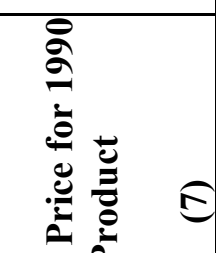 & 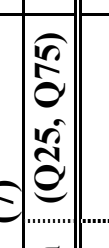 & 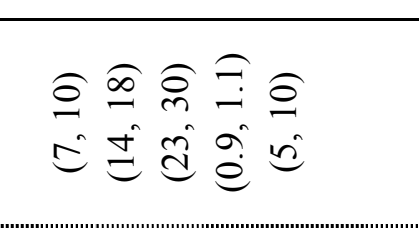 & \\
\hline & 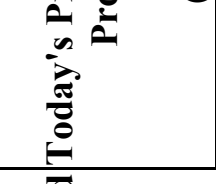 & |z & $\infty \stackrel{\sim}{\sim}-\infty$ & \\
\hline & 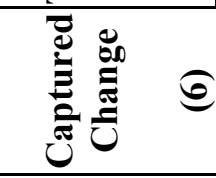 & $\hat{E}$ & 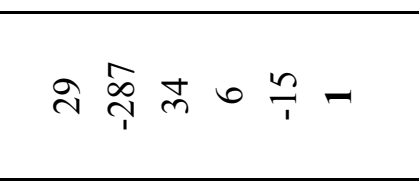 & $=$ \\
\hline & 惫 & $\bar{c}$ & 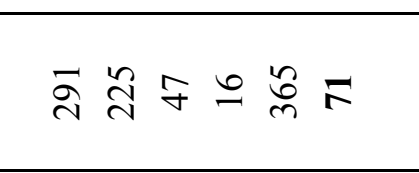 & ले \\
\hline & 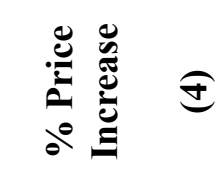 & t & 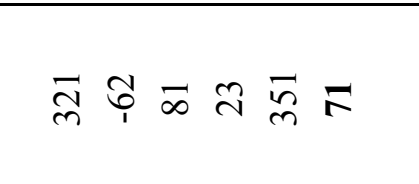 & $\stackrel{8}{\sim}$ \\
\hline & 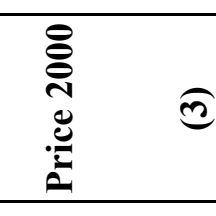 & $\hat{2}$ & $\pm \leadsto / \bar{m}$ & \\
\hline & 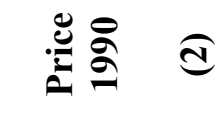 & & $m: \Xi t+$ & \\
\hline & 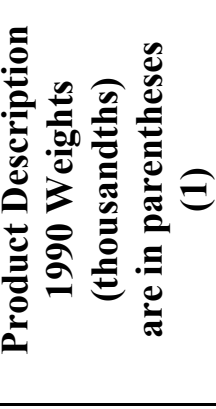 & & 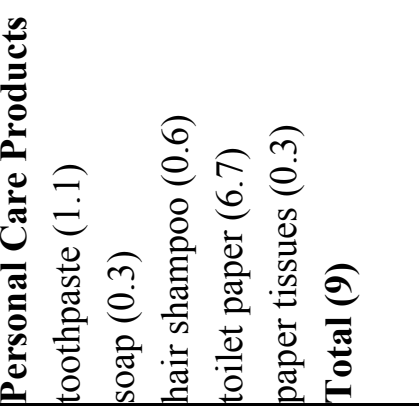 & 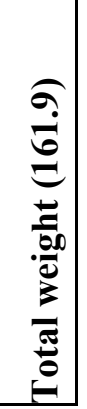 \\
\hline
\end{tabular}




\section{Appendix Table A.1 Number of focus groups and participants evaluating each produ}

\begin{tabular}{|c|c|c|c|c|c|c|c|c|c|}
\hline \multirow[t]{2}{*}{ Product name } & \multirow{2}{*}{$\begin{array}{l}\text { Focus } \\
\text { Groups }\end{array}$} & \multicolumn{3}{|c|}{ Participants } & \multirow{2}{*}{ Product name } & \multirow{2}{*}{$\begin{array}{l}\text { Focus } \\
\text { Groups }\end{array}$} & \multicolumn{3}{|c|}{ Participants } \\
\hline & & Total & Female & Male & & & Total & Female & Male \\
\hline chicken & 2 & 11 & 11 & 0 & milk chocolate & 3 & 18 & 18 & 0 \\
\hline Milk & 1 & 6 & 6 & 0 & jeans & 3 & 17 & 6 & 11 \\
\hline cotton dress & 2 & 11 & 11 & 0 & safety razor & 2 & 12 & 0 & 12 \\
\hline yoghurt & 3 & 17 & 17 & 0 & bread & 6 & 35 & 18 & 17 \\
\hline bed for kids & 1 & 6 & 6 & 0 & coffee & 3 & 18 & 12 & 6 \\
\hline mayonnaise & 2 & 11 & 11 & 0 & ketchup & 3 & 17 & 6 & 11 \\
\hline vacuum cleaner & 2 & 12 & 12 & 0 & cinefilm & 3 & 17 & 0 & 17 \\
\hline electric bulb & 3 & 18 & 6 & 12 & kitchen unit & 3 & 17 & 0 & 17 \\
\hline MF daily & 7 & 42 & 18 & 24 & butter & 4 & 24 & 24 & 0 \\
\hline toothpaste & 3 & 17 & 17 & 0 & night gown & 2 & 12 & 12 & 0 \\
\hline personal car Skoda & 2 & 12 & 0 & 12 & paper tissue & 3 & 18 & 18 & 0 \\
\hline color TV & 2 & 12 & 0 & 12 & roll & 3 & 18 & 18 & 0 \\
\hline refrigerator & 4 & 23 & 0 & 23 & bra & 3 & 18 & 18 & 0 \\
\hline washing machine & 1 & 6 & 0 & 6 & detergent for dishes & 3 & 18 & 18 & 0 \\
\hline bike for kids & 1 & 6 & 0 & 6 & pie & 3 & 18 & 18 & 0 \\
\hline cross country ski & 2 & 12 & 0 & 12 & carbonated water & 2 & 12 & 12 & 0 \\
\hline ice cream & 2 & 12 & 6 & 6 & rose & 2 & 12 & 12 & 0 \\
\hline hotel class $\mathrm{B} / * * *$ & 2 & 12 & 0 & 12 & rape-seed oil & 2 & 12 & 12 & 0 \\
\hline washing powder & 1 & 5 & 5 & 0 & towel & 3 & 18 & 18 & 0 \\
\hline hair shampoo & 2 & 11 & 11 & 0 & repair of car brakes & 3 & 17 & 0 & 17 \\
\hline Soap & 2 & 11 & 5 & 6 & cheese & 2 & 12 & 6 & 6 \\
\hline electric hair dryer & 2 & 11 & 11 & 0 & ladies 'shoes & 2 & 12 & 12 & 0 \\
\hline $\begin{array}{l}\text { cotton sheet, pillow } \\
\text { case }\end{array}$ & 2 & 11 & 11 & 0 & toilet paper & 2 & 12 & 12 & 0 \\
\hline videorecorder & 1 & 6 & 0 & 6 & battery & 3 & 17 & 0 & 17 \\
\hline $\begin{array}{lll}\text { portable radio } & \& \\
\text { tape } & & \end{array}$ & 1 & 6 & 0 & 6 & table lamp & 2 & 11 & 0 & 11 \\
\hline latex painting & 1 & 6 & 0 & 6 & sausages & 2 & 12 & 0 & 12 \\
\hline men's walking shoes & 1 & 6 & 0 & 6 & t-shirt & 1 & 5 & 0 & 5 \\
\hline electric iron & 1 & 6 & 6 & 0 & cinema ticket & 3 & 18 & 6 & 12 \\
\hline women's hadbag & 1 & 6 & 6 & 0 & chewing gum & 4 & 24 & 18 & 6 \\
\hline bananas & 3 & 18 & 18 & 0 & motor oil & 3 & 18 & 0 & 18 \\
\hline Tea & 2 & 12 & 12 & 0 & bottle of wine & 3 & 16 & 16 & 0 \\
\hline drycleaning & 2 & 12 & 12 & 0 & AVERAGE & 2.4 & 13.9 & 8.3 & 5.6 \\
\hline
\end{tabular}




\section{DAVIDSON INSTITUTE WORKING PAPER SERIES - Most Recent Papers}

The entire Working Paper Series may be downloaded free of charge at: www.wdi.bus.umich.edu

CURRENT AS OF 5/03/04

\begin{tabular}{|c|c|c|}
\hline Publication & Authors & Date \\
\hline $\begin{array}{l}\text { No. 681: Consumers' Opinion of Inflation Bias Due to Quality } \\
\text { Improvements }\end{array}$ & $\begin{array}{l}\text { Jan Hanousek and Randall K. } \\
\text { Filer }\end{array}$ & May 2004 \\
\hline $\begin{array}{l}\text { No. 680: IMF-Related Announcements, Fundamentals, and Creditor } \\
\text { Moral Hazard: A Case Study of Indonesia }\end{array}$ & $\begin{array}{l}\text { Ayşe Y. Evrensel and Ali M. } \\
\text { Kutan }\end{array}$ & May 2004 \\
\hline No. 679: Privatization Matters: Bank Efficiency in Transition Countries & $\begin{array}{l}\text { John P. Bonin, Iftekhar Hasan and } \\
\text { Paul Wachtel }\end{array}$ & Apr. 2004 \\
\hline $\begin{array}{l}\text { No. 678: Does Market Liberalisation Reduce Gender Discrimination? } \\
\text { Econometric Evidence from Hungary, 1986-1998 }\end{array}$ & $\begin{array}{l}\text { Dean Jolliffe and Nauro F. } \\
\text { Campos }\end{array}$ & Apr. 2004 \\
\hline $\begin{array}{l}\text { No. 677: Governance and Performance of Microfinance Institutions in } \\
\text { Central And Eastern Europe and the Newly Independent States }\end{array}$ & Valentina Hartarska & Apr. 2004 \\
\hline $\begin{array}{l}\text { No. 676: Equilibrium Exchange Rates in the Transition: The Tradable } \\
\text { Price-Based Real Appreciation and Estimation Uncertainty }\end{array}$ & $\begin{array}{l}\text { Balázs Égert and Kirsten } \\
\text { Lommatzsch }\end{array}$ & Apr. 2004 \\
\hline $\begin{array}{l}\text { No. 675: Productivity growth and the real appreciation of the accession } \\
\text { countries' currencies }\end{array}$ & $\begin{array}{l}\text { Kirsten Lommatzsch and Silke } \\
\text { Tober }\end{array}$ & Apr. 2004 \\
\hline $\begin{array}{l}\text { No. 674: Exchange Rate Policy and Inflation in Acceding Countries: } \\
\text { The Role of Pass-through }\end{array}$ & $\begin{array}{l}\text { Fabrizio Coricelli, Boštjan Jazbec } \\
\text { and Igor Masten }\end{array}$ & Apr. 2004 \\
\hline No. 673: Is Kazakhstan a Market Economy Yet? Getting warmer.... & Sharon Eicher & Apr. 2004 \\
\hline $\begin{array}{l}\text { No. 672: Financial Institutions and The Wealth of Nations: Tales of } \\
\text { Development }\end{array}$ & Jian Tong and Chenggang $\mathrm{Xu}$ & Apr. 2004 \\
\hline $\begin{array}{l}\text { No. 671: Interest Rate Pass-Through in EU Acceding Countries: The } \\
\text { Case of the Czech Republic, Hungary and Poland }\end{array}$ & $\begin{array}{l}\text { Jesús Crespo Cuaresma, Balázs } \\
\text { Égert, and Thomas Reininger }\end{array}$ & Mar. 2004 \\
\hline $\begin{array}{l}\text { No. 670: A minimum of rivalry: evidence from transition economies on } \\
\text { the importance of competition for innovation and growth }\end{array}$ & $\begin{array}{l}\text { Wendy Carlin, Mark Schaffer and } \\
\text { Paul Seabright }\end{array}$ & Mar. 2004 \\
\hline No. 669: Dual Track Liberalization: With and Without Losers & $\begin{array}{l}\text { Jiahua Che and Giovanni } \\
\text { Facchini }\end{array}$ & Mar. 2004 \\
\hline $\begin{array}{l}\text { No. 668: Enterprise Restructuring and Firm Performance: } \\
\text { A Comparison of Rural and Urban Enterprises in Jiangsu Province }\end{array}$ & $\begin{array}{l}\text { Xiao-yuan Dong, Louis } \\
\text { Putterman and Bulent Unel }\end{array}$ & Mar. 2004 \\
\hline $\begin{array}{l}\text { No. 667: A Tale of Two Provinces: The Institutional Environment and } \\
\text { Foreign Ownership in China }\end{array}$ & Yasheng Huang and Wenhua Di & Mar. 2004 \\
\hline $\begin{array}{l}\text { No. 666: Ownership Characteristics and Access to Finance: } \\
\text { Evidence from a Survey of Large Privatised Companies in Hungary } \\
\text { and Poland }\end{array}$ & $\begin{array}{l}\text { Natalia Isachenkova and Tomasz } \\
\text { Mickiewicz }\end{array}$ & Mar. 2004 \\
\hline $\begin{array}{l}\text { No. 665: Testing Creditor Moral Hazard in Sovereign Bond Markets: } \\
\text { A Unified Theoretical Approach and Empirical Evidence }\end{array}$ & $\begin{array}{l}\text { Ayşe Y. Evrensel and Ali M. } \\
\text { Kutan }\end{array}$ & Mar. 2004 \\
\hline $\begin{array}{l}\text { No. 664: Assessing Equilibrium Exchange Rates in CEE Acceding } \\
\text { Countries: Can We Have DEER with BEER without FEER? }\end{array}$ & Balázs Égert & Feb. 2004 \\
\hline $\begin{array}{l}\text { No. 663: Modelling stock returns in the G-7 and in selected CEE } \\
\text { economies: A non-linear GARCH approach }\end{array}$ & Balázs Égert and Yosra Koubaa & Feb. 2004 \\
\hline $\begin{array}{l}\text { No. 662: Institutional Change and Product Composition: Does the Initial } \\
\text { Quality of Institutions Matter? }\end{array}$ & $\begin{array}{l}\text { Johannes Moenius and Daniel } \\
\text { Berkowitz }\end{array}$ & Feb. 2004 \\
\hline No. 661: Dual track liberalization: With and without losers & $\begin{array}{l}\text { Jiahua Che and Giovanni } \\
\text { Facchini }\end{array}$ & Feb. 2004 \\
\hline $\begin{array}{l}\text { No. 660: Who Is in Favor of Enlargement? Determinants of Support for } \\
\text { EU Membership in the Candidate Countries' Referenda }\end{array}$ & Orla Doyle and Jan Fidrmuc & Feb. 2004 \\
\hline $\begin{array}{l}\text { No. 659: Creditor Moral Hazard in Equity Markets: } \\
\text { A Theoretical Framework and Evidence from Indonesia and Korea }\end{array}$ & $\begin{array}{l}\text { Ayşe Y. Evrensel and Ali M. } \\
\text { Kutan }\end{array}$ & Feb. 2004 \\
\hline No. 658: Worsening of the Asian Financial Crisis: Who is to Blame? & $\begin{array}{l}\text { Brasukra G. Sudjana and Ali M. } \\
\text { Kutan }\end{array}$ & Feb. 2004 \\
\hline $\begin{array}{l}\text { No. 657: European Integration, Productivity Growth and Real } \\
\text { Convergence }\end{array}$ & Taner M. Yigit and Ali M. Kutan & Feb. 2004 \\
\hline $\begin{array}{l}\text { No. 656: The Impact of News, Oil Prices, and Global Market } \\
\text { Developments on Russian Financial Markets }\end{array}$ & Bernd Hayo and Ali M. Kutan & Feb. 2004 \\
\hline No. 655: Politics and Economic Reform in Malaysia & Bryan K. Ritchie & Feb. 2004 \\
\hline
\end{tabular}

